\title{
Konferencja "Stanisław Ignacy Witkiewicz. Konteksty filozoficzne, teatralne i filmowe", Instytut Filozofii, Instytut Literatury Polskiej, Uniwersytet Wrocławski, 19-20 listopada 2015
}

Prezentowany numer „Ruchu Filozoficznego” zawiera wybór artykułów przygotowanych na postawie referatów wygłoszonych na ogólnopolskiej konferencji naukowej „Stanisław Ignacy Witkiewicz. Konteksty filozoficzne, teatralne i filmowe", zorganizowanej przez Instytut Filozofii oraz Instytut Filologii Polskiej Uniwersytetu Wrocławskiego. Konferencja odbyła się 19-20 listopada 2015 roku we Wrocławiu. W 2015 roku obchodzono 130. rocznicę urodzin autora Szewców, a Senat RP ogłosił ten rok „Rokiem Witkiewiczów”. Stworzyło to sposobność do ponownego pochylenia się nad twórczością tego wybitnego filozofa, pisarza i malarza, zwłaszcza że przypadała wówczas nie tylko rocznica urodzin Witkiewicza, ale także 80. rocznica wydania jego najważniejszej pracy filozoficznej - Pojęć i twierdzeń implikowanych przez pojęcie Istnienia (1935). Dodatkową okolicznością do namysłu nad tą częścią dorobku tego wszechstronnego twórcy było ukończenie edycji prac stricte filozoficznych Witkacego w ramach Dzieł zebranych, które ukazują się nakładem Państwowego Instytutu Wydawniczego. Pomysł konferencji zrodził się z przekonania, że będąca najrzadziej komentowanym fragmentem dorobku Witkiewicza filozofia zasługuje na większą uwagę badaczy. Artykuły zawarte $\mathrm{w}$ niniejszym numerze kwartalnika są poszerzonymi wersjami tekstów zaprezentowanych w części filozoficznej konferencji. Oprócz nich zostały wygłoszone referaty dotyczące zagadnień filmoznawczych i teatrologicznych. Zestaw ten uzupełniają: artykuł Artura Szachniewicza o koncepcji przestrzeni u Witkiewicza na tle wybranych wątków współczesnej filozofii analitycznej, praca mojego autorstwa, która odnosi się do kategorii ironii w kontekście powieści filozoficz- 
nej Witkiewicza Jedyne wyjście, a także recenzja ostatnio opublikowanej książki o wątkach etycznych w twórczości Witkiewicza.

Program konferencji:

Marek Średniawa (Politechnika Warszawska, Warszawa), Witkacy w siecinie tylko dla dzieci

Izabela Curyłło-Klag (Uniwersytet Jagielloński, Kraków), Witkacy: „net phenomenon". Co wyczyta o nim w sieci anglojęzyczny odbiorca?

Magdalena Gołaczyńska (Uniwersytet Wrocławski, Wrocław), Witkacy w teatrze alternatywnym. Inspiracje biografiq $i$ twórczościq

Przemysław Pawlak (Instytut Witkacego, Warszawa), Witkacy na scenach polskich w latach 1990-2015

Piotr Rudzki (Uniwersytet Wrocławski, Wrocław), Witkacy, Kantor i ten trzeci (Lupa)

Jacek Galewski (Instytut Sztuki PAN, Warszawa), S. I. Witkiewicz i rewolucja. Lektura "Nienasycenia" $i$ "Szewców"

Iwona Grodź, Witkacy Trelińskiego (Uniwersytet im. Adama Mickiewicza w Poznaniu, Poznań)

John Gillies, Witkacy i Malinowski (The University of New South Wales Faculty of Art and Design, Paddington, Australia)

Krzysztof Guczalski (Uniwersytet Jagielloński, Kraków), Czysta Forma a jedność w wielości

Mariusz Oziębłowski (Akademia im. Jana Długosza w Częstochowie, Częstochowa), Funkcje sztuki w teorii Czystej Formy Stanistawa Ignacego Witkiewicza

Przemysław Pawlak (Instytut Witkacego, Warszawa), Czysta Forma - liturgia, geometria i gramatyka dzieła sztuki

Andrzej Ostrowski (Uniwersytet Marii Curie-Skłodowskiej w Lublinie, Lublin), "Ja" jako jedyny przykład bytu samego w sobie i dla siebie

Krzysztof Kościuszko (Uniwersytet Warmińsko-Mazurski w Olsztynie, Olsztyn), Witkacy a problem naturalizacji intencjonalności

Maciej Dombrowski (Uniwersytet Wrocławski, Wrocław), "Jestem w pierwszej kolejności moim ciatem..." - Stanisław Ignacy Witkiewicz a filozofia cielesności

Michał Bizoń (Uniwersytet Jagielloński, Kraków), Starożytnik czyta Witkacego Kamil Sokołowski, Witkacy jako lovemark - eksport, marketing i filozofia polska

Katarzyna Wojewódzka (Uniwersytet Warszawski, Warszawa), Rozmowy istotne i listy jako kontekst dla hermeneutyki St. I. Witkiewicza

Marta Łowejko (Uniwersytet Wrocławski, Wrocław), Filozofia Stanisława Ignacego Witkiewicza a filozofia zdrowego rozsądku

Maciej Dombrowski

Uniwersytet Wrocławski, Wrocław ORCID: 0000-0003-3255-7076 e-mail: maciej.dombrow@gmail.com 